\title{
IS THERE A TIME-TRANSGRESSIVE HOLOCENE OPTIMUM IN THE EAST ASIAN MONSOON AREA?
}

\author{
Weijian Zhou $1,2,3 \bullet$ Shaohua Song ${ }^{1,5} \bullet \mathrm{G} \mathrm{Burr}^{4} \bullet$ A J T Jull ${ }^{4} \bullet$ Xuefeng Lu ${ }^{1,2} \bullet$ Huagui Yu ${ }^{1,5} \bullet$ \\ Peng Cheng 1,5
}

\begin{abstract}
We have carried out a multiproxy analysis of high-resolution eutrophic peat/mud, sand dune, and loess/paleosol sequences covering the Holocene period in both southern and northern China, in order to test the hypothesis of a timetransgressive Holocene optimum in the East Asian monsoon area (An et al. 2000). Samples were radiocarbon dated to establish the chronology. Our results indicate that the Holocene optimum occurred between $\sim 10,000-5000$ cal yr ago in both southern and northern China, consistent with a global pattern rather than simply a local expression. Our data also support the conclusion that the evolution of Holocene climate in China is consistent with changes in Northern Hemisphere solar radiation.
\end{abstract}

\section{INTRODUCTION}

The East Asian monsoon is an integral part of the global climatic system. Monsoon climate, especially monsoon-associated precipitation, is important to the maintenance of living environments and socially sustainable development in the populous regions of East Asia (An et al. 2000). The East Asian monsoon regime is a subsystem of the Asian monsoon circulation (Gao and Xu 1962). The East Asian winter monsoon is linked to cold air flow from high latitudes, and the summer monsoon rains are linked with low-latitude sea surface temperatures (SST) and water vapor. In China, the present summer-monsoon rainfall belt usually consists of discontinuous rain belts that form as the front moves northward. The rainfall belt migrates with the frontal system, leading to the asynchronous onset of summer monsoon precipitation in different areas of the country. The rain belt is stable when the front maintains a quasi-stationary state. Generally, the first such pause occurs in the 2nd week of May in the maritime areas of southern China. The second pause occurs in the 3rd week of June in the area between the Yangtze and Yellow rivers. The third pause, in mid-July, occurs in northern and northeastern China (Figure 1). This concept has led to a model suggesting that Holocene East Asian summer monsoon precipitation reached a maximum in different regions of China at different times in the past (An et al. 2000). From the model, this time-transgressive Holocene optimum would have been experienced 10,000-8000 (9000; values in parentheses are midpoints given in An et al. 2000) cal yr ago in northeastern China, 10,000-7000 (9000) cal yr ago in north-central China, 7000-5000 (6000) cal yr ago in the middle and lower reaches of the Yangtze River, and $\sim 3000 \mathrm{cal}$ yr ago in southern China (Figure 1; An et al. 2000). However, most studies of the Holocene climate history of China have employed a single proxy indicator (e.g. Liu 1989; Shi et al. 1992; Wu et al. 1994; An et al. 2000; Zhou et al. 2002), so this time-transgressive behavior is not always clearly observed in some records. The conclusions from these studies have presented a controversial picture of the post-glacial evolution of regional climate. In order to test this theoretical spatial variation pattern using geological evidence, we have selected 1 peat/mud sequence from southern China and loess/paleosol and sand/paleosol sequences from northern China. We have carried out a multiproxy analysis, including determining geolipids, total organic carbon concentrations, pollen assemblages, and magnetic susceptibility, as well as radiocarbon dating of the deposits.

\footnotetext{
'State Key Laboratory of Loess and Quaternary Geology, Institute of Earth Environment, Chinese Academy of Sciences, Xi'an 710075, China.

${ }^{2} \mathrm{Xi}$ 'an Jiaotong University, China.

${ }^{3}$ Corresponding author. Email: weijian@ loess.llqg.ac.cn.

${ }^{4}$ NSF-AMS Laboratory, Physics Building, Department of Physics, University of Arizona, Tucson, Arizona 85721, USA.

${ }^{5}$ Graduate School of Chinese Academy of Sciences, Beijing 100039, China.
} 


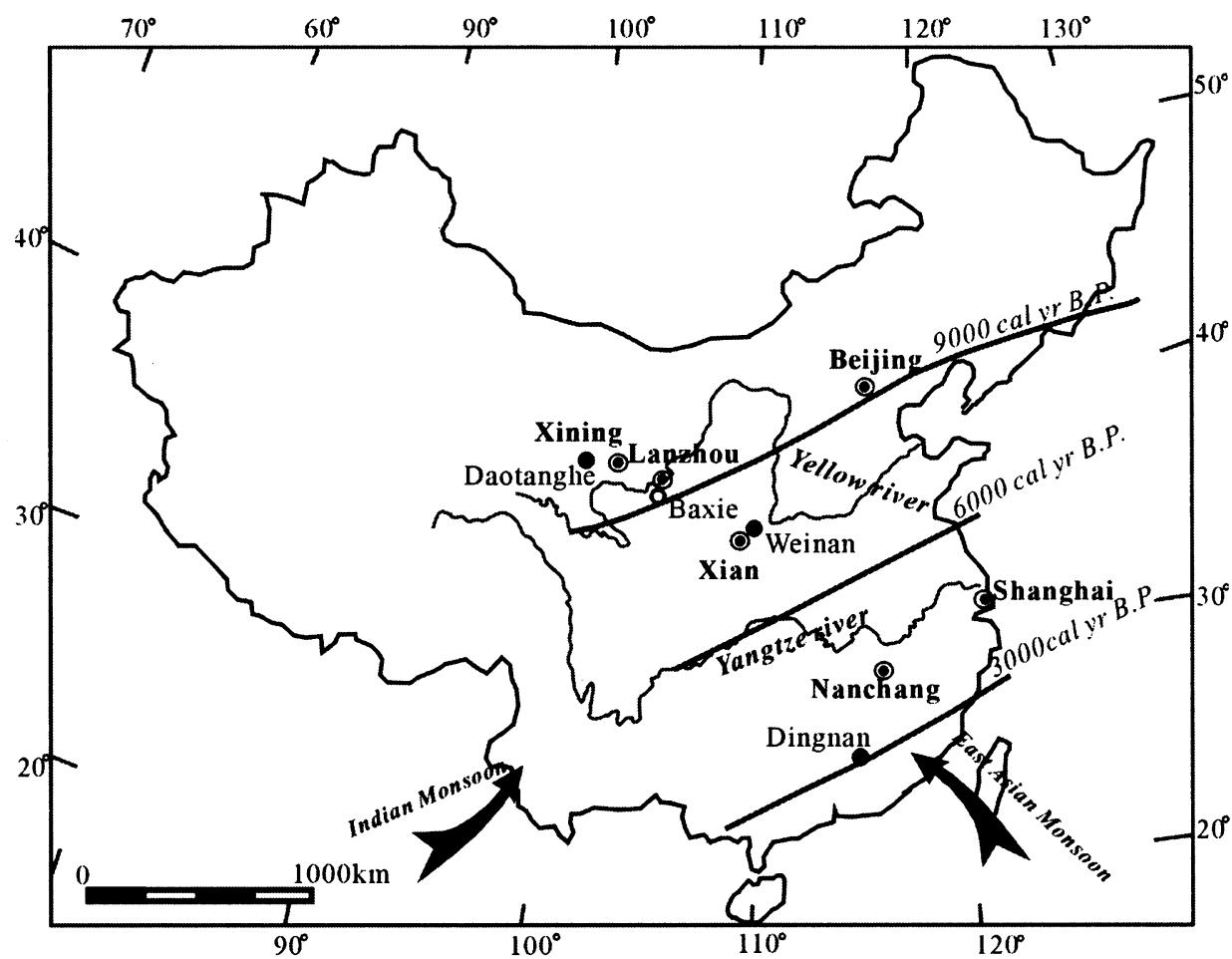

Figure 1 The East Asian monsoon front spatial variation and study locations. The map shows the time-transgressive Holocene optimum (represented by the line representing the monsoon front) would have been experienced $9000 \mathrm{cal}$ yr ago in northeastern and north-central China, $6000 \mathrm{cal} \mathrm{yr}$ ago in the middle and lower reaches of the Yangtze River, and $3000 \mathrm{cal}$ yr ago in southern China (An et al. 2000). Filled circles represent sites for this study; empty circles represent sites for document collection. The sites for this study are located in both the 3000 - and 9000 -yr zones.

\section{STUDY AREAS AND SEDIMENT SEQUENCE}

The study areas are shown in Figure 1. Dingnan Swamp $\left(24^{\circ} 15^{\prime} \mathrm{N}, 115^{\circ} 2^{\prime} \mathrm{E}\right)$ is located at the border of Guangdong and Jiangxi provinces, in the Nanling Mountains area in southern China. The location of the bog in the southern edge of the mid-subtropical zone, not far from the Pacific coast, makes its present climate particularly sensitive to the current East Asian monsoon. The present annual average temperature is $17.8^{\circ} \mathrm{C}$ and the annual precipitation is $1592 \mathrm{~mm}$. Peat is well developed in the hilly basin area. The Dingnan peat deposit is $800 \mathrm{~m}$ long and 50-500 $\mathrm{m}$ wide. The top of the profile (Figure 2), to $0.40 \mathrm{~m}$ depth, consists of brownish-yellow soil cultivated for rice growing. This sequence is underlain $(0.40-1.15 \mathrm{~m})$ by brown, herb-rich peat and by grayish-green mud layers $(1.15-2.10 \mathrm{~m}$ depth). From 2.10 to $3.00 \mathrm{~m}$, grayish-green mud, brown herb peat, and silt-clay containing fine gravel and sand predominate. Below $3.00 \mathrm{~m}$, the sequence consists of a thin sand and gravel layers.

The Weinan loess/paleosol profile $\left(34^{\circ} 20^{\prime} \mathrm{N}, 109^{\circ} 29^{\prime} \mathrm{E}\right)$ is located to the east of Xi' an, Shaanxi Province, and is about $8.00 \mathrm{~m}$ thick. The present annual average temperature is $13.6^{\circ} \mathrm{C}$ and the annual precipitation is $590 \mathrm{~mm}$. The top of the profile, to $2.00 \mathrm{~m}$ depth, consists of sediments mainly modified by farming activities. From 2.00 to $6.00 \mathrm{~m}$, the sequence consists of a loess/paleosol complex. The paleosol complex contains 3 cinnamon paleosol layers intercalated with a layer of loess. Below $6.00 \mathrm{~m}$, there is only a loess horizon (Figure 3). 


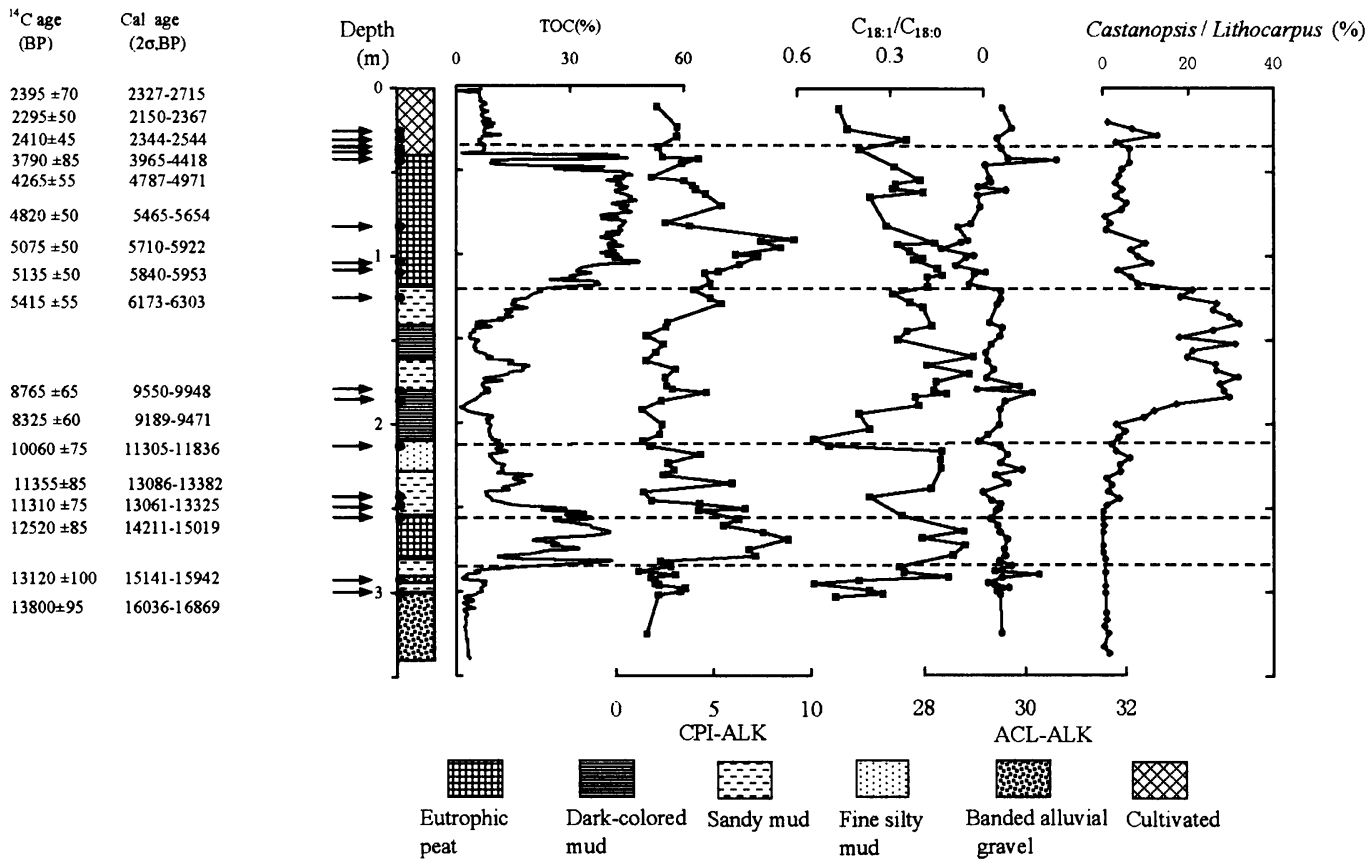

Figure 2 The detailed ${ }^{14} \mathrm{C}$ chronology for the Dignan profile is depicted together with the detailed stratigraphy; $\%$ total organic carbon (TOC); CPI-ALK (the carbon preference index of $n$-alkanes); ACL (the average chain length of $n$-alkanes); the ratio of $\mathrm{C}_{18: 1} / \mathrm{C}_{18: 0}$ fatty acid; and the percent of Castanopsis/Lithocarpus pollen (warm, wet, and sensitive to cold) chosen as the most sensitive proxies reflecting environmental change. $\mathrm{CPI}-\mathrm{ALK}=\Sigma \mathrm{C}_{23-33}$ (odd) $/ \Sigma \mathrm{C}_{22-32}$ (even); $\mathrm{ACL}=$ $\left.\Sigma\left(C_{i} \times\left[C_{i}\right]\right) / \Sigma\left[C_{i}\right]\right)$, where $\left[C_{i}\right]$ is the concentration of the $n$-alkanes with carbon number $C_{i}$, over the range 27-33 (Poynter et al. 1989).

The Daotang He sand dune $\left(36^{\circ} 28^{\prime} \mathrm{N}, 100^{\circ} 55^{\prime} \mathrm{E}\right)$ is located southeast of Lake Qinghai. The profile is named after the nearby Daotang He River, which flows from the northwest into Lake Qinghai. The annual temperature is $0.7{ }^{\circ} \mathrm{C}$ and annual precipitation is $360 \mathrm{~mm}$. The region is at the loess/ desert boundary. Thus, the eolian sand deposit is intercalated with a sandy paleosol. The depth of the sand dune is about $3 \mathrm{~m}$ (Figure 3 ).

\section{EXPERIMENTAL METHODS}

\section{Radiocarbon Dating}

Wet sieving (90-300 $\mu \mathrm{m}$ grain size) was carried out for peat samples to isolate plant fragments from the smaller grain-size muds and silts and rootlets, and for sand dune material to isolate charcoals from the sand/paleosol sequence, as these were believed to be the most reliable dating media (Zhou et al. 1997, 2002, 2004). For the loess/paleosol sequence, it is possible to use chemical separation methods to isolate combined humic acid from non-humic material, such as minerals, and remove mobile organic components from the sample. The $\mathrm{NaOH}$-insoluble fraction from Chinese loess has been shown to be a reliable material for dating (Head et al. 1989; Zhou et al. 1990). We have carried out a comparison study between $\mathrm{NaOH}$-soluble and $\mathrm{NaOH}$-insoluble fractions from a loess/paleosol sequence at Weinan, China. The results show that the $\mathrm{NaOH}$-soluble fraction $(2540 \pm 250 \mathrm{BP})$ is about 700 yr younger than the $\mathrm{NaOH}$-insoluble fraction $(3200 \pm 200 \mathrm{BP})$ from the same paleosol sample. In this case, the $\mathrm{NaOH}$-insoluble fraction was shown to be closer to the true age, since the 


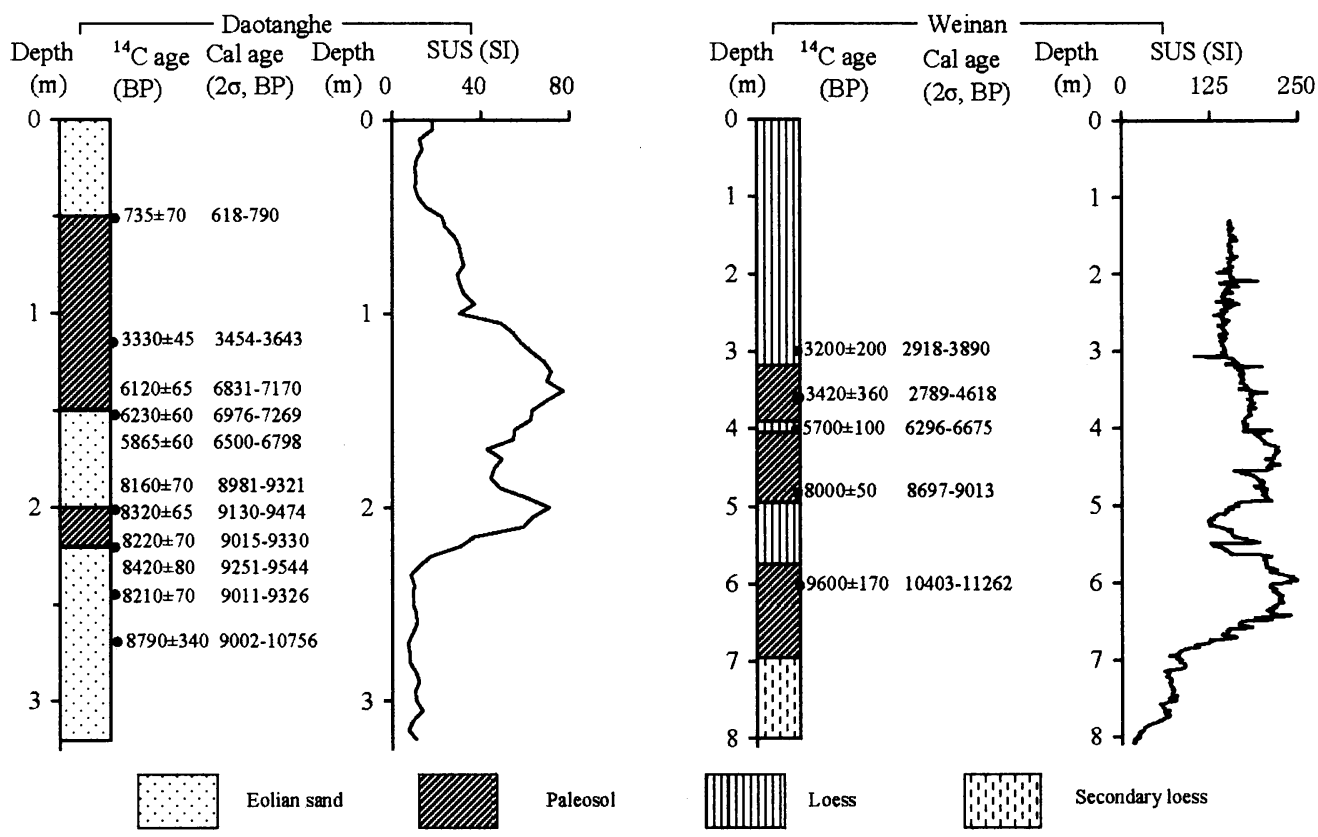

Figure 3 Sand dune magnetic susceptibility for the Dao Tang He site together with that of the loess-paleosol sequence from Weinan site.

loess layer above 300-200 cm contains gray potsherds thought to date to $3000 \mathrm{BP}$. Graphite preparation was performed on $\mathrm{CO}_{2}$ produced by the combustion of the $90-300-\mu \mathrm{m}$ grain-size peat sediment fraction and on charcoal from the sand dune, using the method of Slota et al. (1987). The samples were processed at the State Key Laboratory of Loess and Quaternary Geology, and the targets were measured at the NSF-Arizona Accelerator Mass Spectrometry (AMS) facility. Liquid benzene was prepared on the $\mathrm{NaOH}$-insoluble fraction from loess/paleosol sequences at the State Key Laboratory of Loess and Quaternary Geology in Xi' an and was measured by liquid scintillation counting (LSC) in Xi' an and Australian National University (ANU). Calibrated ages were obtained from these sedimentary boundary ages using CALIB v 5.0.1 software (Stuiver and Reimer 1993) and the IntCal04 calibration curve (Reimer et al. 2004) (see Tables 1-3). The calibrated ages against depth provide the chronological framework by using linear regression based on the 5-order polynomial fitting method.

\section{Magnetic Susceptibility (SUS) Measurement}

The low-frequency $(4.7 \mathrm{kHz})$ magnetic susceptibility (SUS) of samples from the Weinan and Daotanghe loess/sand dune sequences was measured in our laboratory. The section was sampled at 1and 5-cm intervals, respectively. Measured SUS is the induced magnetization of objects in an artificial weak magnetic field. The principle carrier in loess and paleosol sediment is considered to be ultrafine (<1 m) magnetite and maghemite (Kukla and An 1989). The ultrafine single-domain grains display superparamagnetism and provide the main contribution to the SUS signal, which is related to summer monsoon intensity (An et al. 1991). A higher SUS value correlates with strong pedogenesis (Maher and Thompson 1992), a low dust accumulation rate, and therefore with strong summer monsoon circulation. 


\section{Total Organic Carbon and Geolipid Analyses}

Samples for the determination of total organic carbon (TOC) concentrations were taken at $1-\mathrm{cm}$ intervals. TOC concentrations were obtained using a modified Walkley-Black technique (Walkley 1947). Here, the low TOC correlates with an increased amount of sand grains, which suggest wetter conditions with stream deposition, and silt, suggesting lacustrine conditions. Higher TOC suggests "drier" marshy (peat-forming) conditions. We note that these interpretations are different from the traditional one for Chinese peat/sediment sites along the loess-desert transitional zone (Zhou et al. 1996, 1999).

For geolipid analysis, the air-dried sediment samples were first ground to $<80$ mesh. Sediment samples of 1-30 $\mathrm{g}$ were then ultrasonically extracted with chloroform. The dried total extractable lipids were weighed and redissolved in $n$-hexane. The extracts were separated into saturated hydrocarbons, aromatic hydrocarbons, and non-hydrocarbon fractions by silica gel column chromatography (60 mesh) and by sequential elution with $n$-hexane, benzene, and methanol. The saturated hydrocarbons were then directly analyzed by gas chromatography-mass spectrometry (GC-MS) while the non-hydrocarbons were derivatized by heating at $70^{\circ} \mathrm{C}$ for $1.5 \mathrm{hr}$ with $\mathrm{N}$, O-bis (trimethylsilyl) trifluoroacetamide (BSTFA) before GC-MS analysis. $\mathrm{C}_{18: 1} / \mathrm{C}_{18: 0}$ ratios may indicate the amount of degradation of the biomarkers, which are sensitive to paleotemperature changes (Kawamura et al. 1980). The $n$-alkane average chain length (ACL) value is the concentration-weighted mean chain length of the $\mathrm{C}_{27}$ to $\mathrm{C}_{33} n$-alkanes, which have historically been explained by differences in growing-season temperatures and moisture of the source regions (Gagosian and Peltzer 1986; Poynter et al. 1989; Simoneit et al. 1991). In warmer tropical climates, land plants are postulated to biosynthesize longer chain compounds for their waxy coatings, whereas in cooler temperate regions somewhat shorter chain compounds are produced (Gagosian and Peltzer 1986). The $n$-alkane ACL could thus reflect a combination of both humidity and temperature effects. The carbon preference index (CPI) value of the higher molecular weight $n$-alkanes summarizes the relative proportions of evennumbered and odd-numbered carbon molecules in the $n$-alkanoic acid, and $n$-alkane distributions of biological and geological samples (Bray and Evans 1961; Kvenvolden 1966). In fresh lipid material, odd-numbered carbon chains dominate hydrocarbon compositions and even-numbered chains dominate compositions of fatty acids (e.g. Tissot and Welte 1984; Meyers and Ishiwatari 1993). The $n$ alkane CPI value reflecting climate change has been documented in a peat core in northern England (Xie et al. 2004). Under a cold, dry climate, microbial degradation and diagenesis of organic matter are slowed (Kuder and Kruge 1998). Xie et al. (2004) states that such conditions can preserve a high $\mathrm{CPI}$ value. In contrast, a lower CPI value results from the accelerated microbial degradation, and diagenesis of organic matter is associated with a warm, wet climate.

\section{Pollen Analysis}

For pollen analyses, samples were taken every $4 \mathrm{~cm}$, with each pollen sample containing at least 300 grains, using routine laboratory pretreatment methods as described by Pennington and Bonny (1970). For each sample, $5 \mathrm{~cm}^{3}$ were taken, and analyses were carried out using the standard addition of 10,500 grains of Lycopodium spores per sample. The pollen assemblages occurring in the Dingnan peat profile, together with the ecology and distribution characteristics of modern plants in the area, indicate that the most sensitive indices reflecting environmental and climatic change are Alnus, representing a cool and wet environment, and Castanopsis/Lithocarpus (warm, wet, and sensitive to winter temperatures), representing a warm and moist environment. Herb and aquatic plant pollen found in the area include Typha, Potamogeton, Impatiens, Umbelliferae, Gramineae, Ranunculaeae, and Cyperaceae. 


\section{RESULTS AND DISCUSSION}

The results of multiproxy analysis in the Dingnan, Daotanghe, and Weinan profiles are shown in Figures 2 and 3. In relation to Figure 2, we note that because the Dingnan site has always been in the humid subtropical zone, both during and after sedimentation the depositional environment was always wet. High TOC also suggests "drier" marshy (peat-forming) conditions. These interpretations are supported by the overall pollen analyses. We also employed the $n$-alkane CPI as a proxy for relative paleotemperature change. As noted, CPI values should increase when cooler conditions depress $n$-alkane diagenesis and should decrease under warmer conditions. Similarly, lower $\mathrm{C}_{18: 1} /$ $\mathrm{C}_{18: 0}$ ratios indicate greater alterations of fatty acids under warmer conditions. The $n$-alkane ACL is a potential proxy for changes in both humidity and temperature. When humidity and temperature increase, the ACL is higher. Pollen such as Castanopsis/Lithocarpus (warm, wet, and sensitive to winter temperature) is the most diagnostic index to reconstruct environmental changes in this region. Zhou et al. (2004) conclude that high values of the ratio of Castanopsis and Lithocarpus pollen, both broad-leaved evergreen trees, indicate a warm and moist environment. Our multiproxies show that the Dingnan peat bog experienced 5 major changes during the last $16 \mathrm{kyr}$ BP.

\section{Dingnan Site}

Figure 2 depicts the stratigraphic sequence at Dingnan and its ${ }^{14} \mathrm{C}$ chronology, which is also shown in Table 1. Detailed examination of the sediments shows that all proxies (TOC from $2-42 \%$, CPIALK from 1.3-9.0, $\mathrm{C}_{18: 1} / \mathrm{C}_{18: 0}$ from 0.03-0.55, ACL-ALK from 28-30.6, and Castanopsis/Lithocarpus from $0.5-32 \%$ ) fluctuated with time.

Table $1{ }^{14} \mathrm{C}$ data for Dingnan. All samples are $90-300 \mu \mathrm{m}$ peat.

\begin{tabular}{lcccc}
\hline Sample nr & Lab code $^{\mathrm{a}}$ & $\begin{array}{l}\text { Depth } \\
(\mathrm{cm})\end{array}$ & $\begin{array}{l}{ }^{14} \mathrm{C} \text { age } \\
(\mathrm{BP})\end{array}$ & $\begin{array}{l}\text { Cal age BP } \\
(2 \sigma)\end{array}$ \\
\hline JXDN30 & AA29575 & 30 & $2395 \pm 70$ & $2327-2715$ \\
JXDN35 & AA29574 & 35 & $2295 \pm 50$ & $2150-2367$ \\
JXDN40 & AA33735 & 40 & $2410 \pm 45$ & $2344-2544$ \\
JXDN43 & AA32053 & 43 & $3790 \pm 85$ & $3965-4418$ \\
JXDN47 & AA33736 & 47 & $4265 \pm 55$ & $4787-4971$ \\
JXDN83 & AA31665 & 83 & $4820 \pm 50$ & $5465-5654$ \\
JXDN105 & AA33737 & 105 & $5075 \pm 50$ & $5710-5922$ \\
JXDN110 & AA31666 & 110 & $5135 \pm 50$ & $5840-5953$ \\
JXDN126 & AA31667 & 126 & $5415 \pm 50$ & $6173-6303$ \\
JXDN180 & AA31668 & 180 & $8765 \pm 65$ & $9550-9948$ \\
JXDN185 & AA29572 & 185 & $8325 \pm 60$ & $9189-9471$ \\
JXDN211 & AA31699 & 211 & $10,060 \pm 75$ & $11,305-11,836$ \\
JXDN240 & AA31670 & 240 & $11,355 \pm 85$ & $13,086-13,382$ \\
JXDN245 & AA33744 & 245 & $11,310 \pm 75$ & $13,061-13,325$ \\
JXDN251 & AA31671 & 251 & $12,520 \pm 85$ & $14,211-15,019$ \\
JXDN290 & AA29571 & 290 & $13,120 \pm 100$ & $15,141-15,942$ \\
JXDN296 & AA31672 & 296 & $13,800 \pm 95$ & $16,036-16,869$ \\
\hline${ }^{a}$ AA lab code of the NSF-AMS facility, University of Arizona, Tucson, Arizona, USA.
\end{tabular}

From $\sim 15.6$ to $14.3 \mathrm{kyr}$ cal BP (2.80-2.52 m), the first organic carbon-rich peat layer accumulated. High TOC indicates drier conditions. High $n$-alkane carbon preference index (CPI) values suggest organic matter degradation was suppressed, but low $C_{18: 1} / C_{18: 0}$ values contradict this interpretation. Average chain length (ACL) values gradually decrease. The ratio of Castanopsis/Lithocarpus indicates a cool and wet climate, which is consistent with peat formation. 
From 14.3 to $11.5 \mathrm{kyr}$ cal BP $(2.52-2.10 \mathrm{~m})$, all of the proxies vary erratically, which suggests that this may be a period of unstable climate. At $2.52 \mathrm{~m}$, there is a layer of coarse sand, which signifies a change in sedimentary facies to dark-gray fluvial muds. This facies change occurs at $\sim 14.3 \mathrm{kyr}$ cal $\mathrm{BP}$, which agrees with the age assigned to the onset of the Bølling-Allerød interstadial (Wang et al. 2001). All proxies indicate wet and cool conditions. At $2.28 \mathrm{~m}$, there is a distinct change to a lighter colored muddy/silty sediment coinciding with the onset of the Younger Dryas (YD) stade (12.9 kyr cal BP; Grootes et al. 1993; Sowers and Bender 1995; Wang et al. 2001). Alnus is dominant (Xiao et al. 1998), indicating constant cool, wet conditions, and the presence of silty muds in this unit suggests water depths reached their maximum for the entire sequence, contrasting with the high-latitude (cold, dry) response to the YD event. This observation is supported by work published elsewhere (Zhou et al. 1996, 2001, 2004).

From 11.5 to $6.0 \mathrm{kyr}$ cal BP $(2.10-1.15 \mathrm{~m})$, there are alternations of dark-colored lake mud and lighter sandy or coarse mud accumulations; together they have the lowest TOC percentage. Low $\mathrm{CPI}$ values and $\mathrm{C}_{18: 1} / \mathrm{C}_{18: 0}$ ratios, a relatively high $n$-alkane $\mathrm{ACL}$, and a high Castanopsis/Lithocarpus pollen ratio imply a period of possible higher temperature and precipitation. During this period, we estimate the average precipitation was $\sim 1800 \mathrm{~mm}$ and average temperature was about $1-2{ }^{\circ} \mathrm{C}$ above present, based on comparison with modern vegetation. Hence, this interval represents the Holocene optimum rather than the 6000 or 3000 yr pointed out by An et al. (2000). We also know the optimum occurred at the time of maximum Northern Hemisphere insolation, which reinforces the solar radiation forcing concept.

From 6.0 to $3.8 \mathrm{kyr}$ cal BP $(1.15-0.40 \mathrm{~m})$, a second organic carbon-rich peat layer accumulated. TOC and $n$-alkane CPI values are high, $\mathrm{C}_{18: 1} / \mathrm{C}_{18: 0}$ values increase, and $\mathrm{ACL}$ values decrease. The Castanopsis/Lithocarpus ratios decline and the proportions of tree pollen decrease, whereas those of grass and fern pollen increase (Zhou et al. 2004). The concordance of these proxy changes indicates a change to a drier and cooler mid-Holocene climate.

After $3.8 \mathrm{kyr}$ cal BP $(0.40-0 \mathrm{~m})$, the sedimentary record is strongly disturbed by human activities. Not all of the proxies can be used for interpreting paleoclimatic signals due to the consequences of rice paddy farming and associated elevated methanogenic bacterial activity in the water-saturated soil.

\section{Daotanghe and Weinan Sites}

Figure 3 shows that the higher peak magnetic susceptibility of Daotanghe is bracketed between 4000-9300 cal BP, during which time the sandy paleosol was strongly developed, although there is a fluctuation of the lower magnetic susceptibility around $9000 \mathrm{cal}$ BP. The profile indicates that a combination of higher temperature and higher precipitation occurred during $~ 4000-9000$ cal BP; after $\sim 4000$ cal BP, magnetic susceptibility decreased.

Magnetic susceptibility in the Weinan profile reached higher values from $\sim 5000-10,900 \mathrm{cal} \mathrm{BP}$, in correspondence with the development of the 2-layer paleosols. After $5000 \mathrm{cal}$ BP, magnetic susceptibility decreased. The top $1.5 \mathrm{~m}$ of loess is modified by farming and cannot therefore be used for this study.

An et al. (1991) recognized that the magnetic susceptibility signal is related to summer monsoon intensity: the higher the value, the stronger the summer monsoon. Both the Daotanghe and Weinan loess/paleosol sequences in Figure 3 indicate a Holocene optimum represented by higher magnetic susceptibility ranges from $\sim 4000$ to $10,000 \mathrm{cal} \mathrm{BP}$. 
Table $2{ }^{14} \mathrm{C}$ data for Weinan.

\begin{tabular}{llllcc}
\hline Sample nr & Lab code $^{\mathrm{a}}$ & $\begin{array}{l}\text { Depth } \\
(\mathrm{cm})\end{array}$ & Sample type & $\begin{array}{l}{ }^{14} \mathrm{C} \text { age } \\
(\mathrm{BP})\end{array}$ & $\begin{array}{l}\text { Cal age BP } \\
(2 \sigma)\end{array}$ \\
\hline C28 & ANU6201 & 300 & NaOH-insoluble paleosol & $3200 \pm 200$ & $2919-3896$ \\
C27 & ANU6202 & 350 & NaOH-insoluble paleosol & $3420 \pm 360$ & $2789-4618$ \\
C13 & XLLQ111 & 400 & NaOH-insoluble paleosol & $5700 \pm 100$ & $6298-6679$ \\
C12 & XLLQ37 & 480 & NaOH-insoluble paleosol & $8000 \pm 80$ & $8603-9032$ \\
C11 & XLLQ104 & 600 & Organic of Ca nodule & $9600 \pm 170$ & $10,413-11,344$ \\
C25 & ANU6393 & 950 & NaOH-soluble (mud) & $14,000 \pm 1700$ & $12,564-20,646$ \\
\hline
\end{tabular}

${ }^{\mathrm{a}} \mathrm{ANU}=$ lab code of the Australian National University; XLLQ = lab code of the Xi' an Laboratory of Loess and Quaternary Geology.

Table $3{ }^{14} \mathrm{C}$ data for Daotanghe.

\begin{tabular}{llclrc}
\hline Sample nr & Lab code $^{\mathrm{a}}$ & $\begin{array}{l}\text { Depth } \\
(\mathrm{cm})\end{array}$ & Material & $\begin{array}{l}{ }^{14} \mathrm{C} \text { age } \\
(\mathrm{BP})\end{array}$ & $\begin{array}{l}\text { Cal age BP } \\
(2 \sigma)\end{array}$ \\
\hline $980703-01$ & AA32744 & 50 & Charcoal & $735 \pm 70$ & $618-790$ \\
$980703-02$ & AA32755 & 125 & Charcoal & $3330 \pm 45$ & $3454-3643$ \\
DTH-032 & AA12325 & 150 & Charcoal & $6120 \pm 65$ & $6831-7170$ \\
DTH-031 & AA12326 & 150 & Charcoal & $6230 \pm 60$ & $6976-7269$ \\
$980703-03$ & AA31609 & 150 & Charcoal & $5865 \pm 60$ & $6500-6798$ \\
DTH-027 & AA12320 & 200 & Charcoal & $8160 \pm 70$ & $8981-9321$ \\
$980703-04$ & AA31608 & 200 & Charcoal & $8320 \pm 65$ & $9130-9474$ \\
DTH-034 & AA12323 & 220 & Mix-charcoal & $8420 \pm 80$ & $9251-9544$ \\
DTH-033 & AA12324 & 220 & Charcoal & $8220 \pm 70$ & $9015-9330$ \\
DTH-028 & AA12321 & 245 & Charcoal & $8210 \pm 70$ & $9011-9326$ \\
$980703-08$ & AA31598 & 270 & Charcoal & $8790 \pm 340$ & $9002-10,756$ \\
\hline
\end{tabular}

${ }^{\mathrm{a} A A}=$ lab code of the NSF-AMS facility, University of Arizona, Tucson, Arizona, USA.

\section{Climatic Proxies Along a North-South Gradient}

Figure 4a presents proxies covering a north-south gradient from Dingnan peat to the Weinan loess sequence and Baxie loess sequence (Zhou et al. 1992; An et al. 1993) along the arid to semi-arid transitional zone. Between $\sim 10,000$ and $5000 \mathrm{cal} \mathrm{BP}$, the lipid, pollen, and SUS proxies reflect the largest precipitation and maximum temperatures - though there are fluctuations-and the intensity of summer solar radiation in the Northern Hemisphere reached a maximum. The observations and the simulated hydrologic budgets from the CCM covering the latitudinal belt from $8.9^{\circ}$ to $26.6^{\circ} \mathrm{N}$ agree, so that the highest lake level and largest excess of precipitation over evaporation are placed in the 9000- to 6000-yr period (COHMAP members 1988). Therefore, it is appropriate to label this period as the Holocene optimum (Figures 2, 3, and 4). This timing is basically consistent with the Holocene optimum found globally. Unfortunately, there is a 1000 -yr error for the Holocene optimum because the start and termination of climatic proxies are different, and dating error is involved. These geological records are also supported by the summer monsoon index of the numerical modeling (An et al. 2000; see also Figure 4b). The modeling results show that the East Asian monsoon reached a maximum around $9000 \mathrm{yr}$, which is coincident with the peak in Northern Hemisphere solar insolation. It is interesting to note the contrast to the Indian monsoon, which peaked around $12,000 \mathrm{yr}$, some $3000 \mathrm{yr}$ before the East Asian monsoon. 


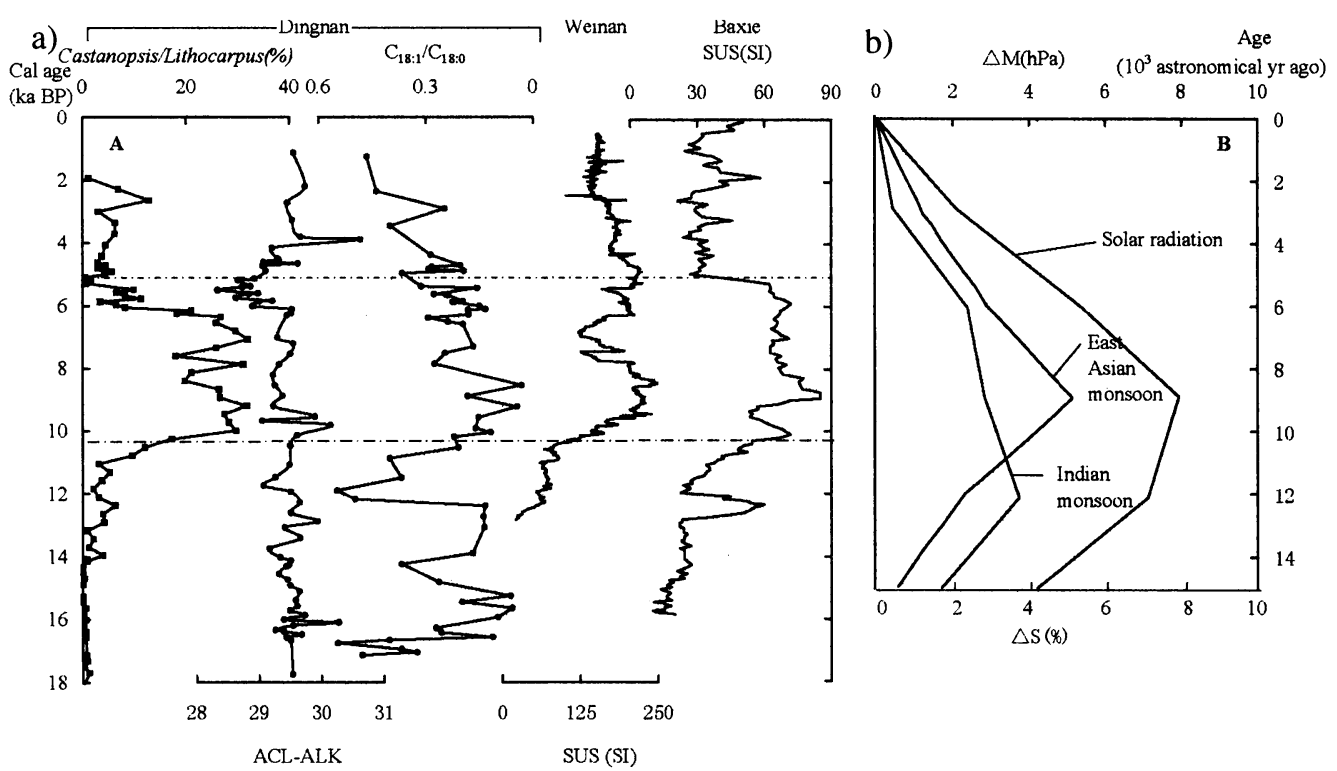

Figure 4 a) Documentation of multiproxies from a north-south gradient in China illustrating the Holocene optimum. The \% TOC, ACL-ALK, and \% Castanopsis/Lithocarpus pollen proxies are given for Dingnan Swamp; the magnetic susceptibility is given for the Weinan loess sequence and for the Baxie site (Zhou et al. 1992; An et al. 1993) along the arid to semi-arid transitional zone. b) The numerical modeling result shows that solar radiation anomaly (departure from present) $(\Delta S)$ compared with the East Asian monsoon index (the difference of sea-level pressure between $160^{\circ}$ and $110^{\circ} \mathrm{E}$ longitude along $25-50^{\circ} \mathrm{N}$ latitude) and the tropical Indian monsoon index (the difference of sea-level pressure between ocean and land within the region $45^{\circ}$ to $120^{\circ} \mathrm{E}$ longitude and $45^{\circ} \mathrm{N}$ and $15^{\circ} \mathrm{S}$ latitude $[\Delta \mathrm{M}(\mathrm{hpa})]$ ) at $3000-\mathrm{yr}$ intervals since $15 \mathrm{kyr}$ calendar yr BP. The monsoon indices are calculated from the climate model simulation for July using CCM0 (after An et al. 2000).

In summary, our results do not support the earlier suggestion of a time-transgressive Holocene optimum in China at the millennial scale (An et al. 2000). Our comparison of the north-south gradient also supports the idea that solar forcing is one of the main factors controlling the East Asian monsoon climate. Our results also show the importance of accurate ${ }^{14} \mathrm{C}$ dating, as a reliable age depends on the material dated. It is worthwhile to mention that our chemical pretreatment of samples still provides a few reversed ages; however, this may be caused by bioturbation, or perhaps our pretreatment for some samples still needs further refinement. Careful attention to the chemical pretreatment of samples is important for future studies.

\section{ACKNOWLEDGMENTS}

The authors gratefully acknowledge the support of the "Wang KC Education Foundation, Hong Kong," NKPBR-2004CB720200, and NSFC 40531003, 40121303, and 40523002. The work at the University of Arizona is supported by a US National Science Foundation grant EAR0448461. The authors also thank the staff of the NSF-Arizona AMS facility for their technical support.

\section{REFERENCES}

An ZS, Kukla GJ, Porter SC, Xiao JL. 1991. Magnetic susceptibility evidence of monsoon variation on the Loess Plateau of central China during the last 130,000 years. Quaternary Research 36(1):29-36.

An ZS, Porter SC, Zhou WJ, Lu YC, Donahue DJ, Head
MJ, Wu XH, Ren JS, Zheng HB. 1993. Episode of strengthened summer monsoon climate of Younger Dryas age on the Loess Plateau of central China. Quaternary Research 39(1):45-54.

An ZS, Porter SC, Kutzbach JE, Wu XH, Wang SM, Liu 
XD, Li XQ, Zhou WJ. 2000. Asynchronous Holocene optimum of the East Asian monsoon. Quaternary Science Reviews 19(8):743-62.

Bray EE, Evans ED. 1961. Distribution of $n$-paraffins as a clue to the recognition of source beds. Geochimica et Cosmochimica Acta 22(1):2-15.

COHMAP members. 1988. Climatic changes of the last 18,000 years: observations and model simulations. Science 241(4869): 1043-52.

Gagosian RB, Peltzer ET. 1986. The importance of atmospheric input of terrestrial organic material to deep sea sediments. Organic Geochemistry 10(4-6):661-9.

Gao YX, Xu SY. 1962. Some Problems of East Asian Monsoon. Beijing: Science Press. 49 p. In Chinese.

Grootes PM, Stuiver M, White JWC, Johnsen S, Jouzel J. 1993. Comparison of oxygen isotope records from the GISP2 and GRIP Greenland ice cores. Nature 366(6455):552-4.

Head MJ, Zhou WJ, Zhou MF. 1989. Evaluation of ${ }^{14} \mathrm{C}$ ages of organic fractions of paleosols from loess-paleosol sequences near Xian, China. Radiocarbon 31(3):680-96.

Kawamura K, Ishiwatari R, Ogura K. 1980. Early diagenesis of organic matter in the water column and sediments: microbial degradation and resynthesis of lipids in Lake Haruna. Organic Geochemistry 11(4): 251-64.

Kuder T, Kruge MA. 1998. Preservation of biomolecules in sub-fossil plants from raised peat bogs-a potential paleoenvironmental proxy. Organic Geochemistry 29(5-7):1355-68.

Kukla G, An ZS. 1989. Loess stratigraphy in central China. Palaeogeography, Palaeoclimatology, Palaeoecology 72:203-25.

Kvenvolden KA. 1966. Evidence for transformations of normal fatty acids in sediments. In: Hobson GD, editor. Advances in Organic Geochemistry 1964: Proceedings of the International Meeting in Rueil-Malmaison. Oxford: Pergamon Press. p 335-66.

Liu J. 1989. Vegetational and climatic changes at Gushantun Bog in Jilin, NE China since 13,000 BP. Acta Palaeontologica Sinica 28:240-8. In Chinese.

Maher BA, Thompson R. 1992. Paleoclimatic significance of the minimal magnetic record of the Chinese loess and paleosols. Quaternary Research 37(2):15570.

Meyers PA, Ishiwatari R. 1993. Lacustrine organic geochemistry - an overview of indicators of organic matter sources and diagenesis in lake sediments. Organic Geochemistry 20(7):867-900.

Pennington W, Bonny AP. 1970. Absolute pollen diagram from the British late-glacial. Nature 226(5248): 871-2.

Poynter JG, Farrimond P, Brassell SC, Eglinton G. 1989. Aeolian-derived higher-plant lipids in the marine sedimentary record: links with paleoclimate. In: Leinen M, Sarnthein M, editors. Palaeoclimatology and
Palaeometeorology: Modern and Past Patterns of Global Atmosphere Transport. Dordrecht: Kluwer Academic. p 435-62.

Reimer PJ, Baillie MGL, Bard E, Bayliss A, Beck JW, Bertrand CJH, Blackwell PG, Buck CE, Burr GS, Cutler KB, Damon PE, Edwards RL, Fairbanks RG, Friedrich M, Guilderson TP, Hogg AG, Hughen KA, Kromer B, McCormac G, Manning S, Bronk Ramsey C, Reimer RW, Remmele S, Southon JR, Stuiver M, Talamo S, Taylor FW, van der Plicht J, Weyhenmeyer CE. 2004. IntCal04 terrestrial radiocarbon age calibration, 0-26 cal kyr BP. Radiocarbon 46(3):1029-58.

Shi YF, Kong ZC, Wang SM, Tang LY, Wang FB, Chen YD, Zhao XT, Zhang PY, Shi SH. 1992. Basic features of climate and environment during the Holocene megathermal in China. Science of China Series B 35: 1300-8. In Chinese.

Simoneit BRT, Cardoso JN, Robinson N. 1991. An assessment of terrestrial higher molecular weight lipid compounds in aerosol particulate matter over the South Atlantic from about $30-70^{\circ} \mathrm{S}$. Chemosphere 23(4):447-65.

Slota Jr PJ, Jull AJT, Linick TW, Toolin LJ. 1987. Preparation of small samples for ${ }^{14} \mathrm{C}$ accelerator targets by catalytic reduction of CO. Radiocarbon 29(2):303-6.

Sowers T, Bender M. 1995. Climate records covering the last deglaciation. Science 269(5221):210-4.

Stuiver M, Reimer PJ. 1993. Extended ${ }^{14} \mathrm{C}$ data base and revised CALIB $3.0{ }^{14} \mathrm{C}$ age calibration program. $\mathrm{Ra}$ diocarbon 35(1):215-30.

Tissot BP, Welte DH. 1984. Petroleum Formation and Occurrence. 2nd edition. Berlin: Springer-Verlag. $699 \mathrm{p}$.

Walkley A. 1947. A critical examination of a rapid method for determination of organic carbon in soils effect of variations in digestion conditions and of inorganic soil constituents. Soil Science 63:251-7.

Wang YJ, Cheng H, Edwards RL, An ZS, Wu JY, Shen CC, Dorale JA. 2001. A high-resolution absolutedated late Pleistocene monsoon record from Hulu Cave, China. Science 294(5550):2345-8.

Wu XH, An ZS, Wang SM, Liu XD, Li XQ, Zhou WJ, Liu JF, Lu JJ. 1994. The spatial and temporal variations of the East Asian summer monsoon on the Holocene optimum of China. Quaternary Science Research 1:24-35. In Chinese.

Xiao JY, Wang J, An ZS, Wu XH, Zhou WJ. 1998. Evidence for the Younger Dryas event in the eastern part of Nanling region. Acta Botanica Sinica 40(11):1079_ 82. In Chinese.

Xie S, Nott CJ, Avsejs LA, Maddy D, Chambers FM, Evershed RP. 2004. Molecular and isotopic stratigraphy in an ombrotrophic mire for paleoclimate reconstruction. Geochimica et Cosmochimica Acta 68(13): 2849-62.

Zhou WJ, Zhou MF, Head MJ. 1990. ${ }^{14} \mathrm{C}$ chronology of Beizhuangcun sedimentation sequence since 30,000 
years BP. Chinese Science Bulletin 35(7):567-72.

Zhou WJ, An ZS, Lin BH, Xiao JL, Zhang JZ, Xie J, Zhou MF, Porter SC, Head MJ, Donahue DJ. 1992. Chronology of the Baxie loess profile and the history of monsoon climates in China between 17,000 and 6000 years BP. Radiocarbon 34(3):818-25.

Zhou WJ, Donahue DJ, Porter SC, Jull AJT, Li XQ, Stuiver M, An ZS, Matsumoto E, Dong GR. 1996. Variability of monsoon climate in east Asia at the end of the last glaciation. Quaternary Research 46(3): 219-29.

Zhou WJ, Donahue D, Jull AJT. 1997. Radiocarbon AMS dating of pollen concentrated from eolian sediments: implications for monsoon climate change since the late Quaternary. Radiocarbon 39(1):19-26.

Zhou WJ, Head MJ, Lu XF, An ZS, Jull AJT, Donahue D. 1999. Teleconnection of climatic events between East Asia and polar, high latitude areas during the last de- glaciation. Palaeogeography, Palaeoclimatology, Palaeoecology 152(1-2):163-72.

Zhou WJ, Head MJ, An ZS, Deckker De P, Liu ZY, Liu XD, Lu XF, Donahue D, Jull AJT, Beck JW. 2001. Terrestrial evidence for a spatial structure of tropical-polar interconnections during the Younger Dryas episode. Earth and Planetary Science Letters 191(3-4): 231-9.

Zhou WJ, Lu XF, Wu ZK, Deng L, Jull AJT, Donahue D, Beck W. 2002. Peat record reflecting Holocene climatic change in the Ruoergai Plateau and AMS radiocarbon dating. Chinese Science Bulletin 47(1):66-70.

Zhou WJ, Yu XF, Jull AJT, Burr G, Xiao JY, Lu XF, Xian F. 2004. High-resolution evidence from southern China of an early Holocene optimum and a mid-Holocene dry event during the past 18,000 years. Quaternary Research 62(1):39-48. 